\title{
INTEGRATION OF THREE-DIMENSIONAL DIGITAL MODELS AND 3D GIS: THE DOCUMENTATION OF THE MEDIEVAL BURIALS OF AMITERNUM (L'AQUILA, ITALY)
}

\author{
I. Trizio ${ }^{1}$, F. Savini ${ }^{2}$, A. Giannangeli ${ }^{1}$ \\ ${ }^{1}$ ITC-CNR, Institute for Construction Technology, Italian National Research Council, L'Aquila, Italy - (ilaria.trizio, \\ alessandro.giannangeli) @itc.cnr.it \\ ${ }^{2}$ Department of Human Studies, University of L'Aquila, Italy - fransav83@gmail.com
}

\author{
Commission II, WG II/8
}

KEY WORDS: 3D GIS, Documentation of Cultural Heritage, Archaeological Heritage, Digital Photogrammetry, Archaeological Survey, $3 \mathrm{~d}$ modelling of archeological data

\begin{abstract}
:
This paper illustrates the results of an experimentation carried out by a multi-disciplinary research group made up of researchers from ITC-CNR of L'Aquila and of archaeologists of the University of L'Aquila. The research project carried out by the team is based on the analysis of the archaeological heritage (in particular, the documentation of some burials found in the medieval site of Amiternum, near L'Aquila). This starts from methods based on digital photogrammetric restitution, based on Structure from Motion (SfM) algorithms, and the generation of photorealistic textures in order to manage, in a 3D GIS environment, complex archaeological and anthropological data. The choice of technology to use is often determined by the specific needs of the survey, the purpose of the project, the budget and experience of the researchers, and the geometric characteristics of the assets, rather than the precision to be achieved. For the survey of the archaeological excavation of the medieval site of Amiternum, it was decided to use digital photogrammetry given that the objective was to document, with a rapid survey compatible with the times of an archaeological excavation the phases of image acquisition, processing and post processing of the site model. Furthermore, thanks to the integration of two technologies, digital photogrammetry and GIS, and the undisputed improvement in the management of 3D data by the GIS, three-dimensionality, in archeology in general, has become an indispensable component for site interpretation and for the documentation of the data.
\end{abstract}

\section{3D GIS FOR DOCUMENTING ARCHAEOLOGICAL CONTEXTS}

Archaeologists quickly understood, before other professionals, the potential of Information and Communication Technology (ICT) in general, and Geographic Information Systems (GIS) in particular, for documenting and managing data originated by stratigraphic excavations or from architecture stratigraphic analysis. Already at the end of the nineties, several authoritative archaeology contributions in the literature made this point (one only need to cite Forte 1997 or Forte 2002), and many applications to a range of case studies were reported, which helped improve the workflow from data acquisition to their interpretation.

As these experiences flourished, and were applied to different scale levels, archaeologists increasingly found themselves working in multi-disciplinary teams and, over time, dealing with three-dimensional data. Although the nineties marked the first approaches to archaeological data managed in a GIS environment, it is the new millennium that brought archaeology to deal with managing three-dimensional data, the fourth dimension and virtual reality applications (Forte, Campana 2017).

\subsection{The state of the art}

Even though, from a methodology standpoint, the need to visualize three-dimensional archaeological data in GIS environments had been evident from some time, the first applications were mainly Digital Elevation Models (DEMs) and Triangulated Irregular Networks (TINs), for which the concept of three dimensions was mostly linked to the quotas of represented points.
As for the first true applications of 3D GIS, experimentations began with the analysis of architectural contexts (Continenza, Trizio 2015) which, naturally, followed the pace of software developments and thus only recently began to feature adequate levels of visualization, management and analysis of threedimensional data (think of proprietary software such as ArcGIS by ESRI, which enabled direct management of threedimensional data through the Arc Scene module, launched in 2008). Within the archaeology domain, several research groups experimented representing archaeological contexts through three-dimensional meshes (acquired through laser scans or digital photogrammetry) with high resolution texture in 3D GIS environments.

A good review of the state of the art was recently published (Dell'Unto 2017) but even there, most experiences come from the research projects carried out by the Digital Archaeology Laboratory (DARK Lab) of the University of Lund, in Sweden (Landeschi 2016; Landeschi et alii 2016; Dell'Unto et alii 2016; Leander Touati 2016) and by the Dig@Lab at Duke University (Forte 2015) while Italian research groups have carried out more recent applications that have greater links with threedimensional stratigraphic analysis of architectural archaeology (Trizio et alii, in review; Nucciotti 2017).

\subsection{Integrating GIS and 3D digital models}

As highlighted by those who have experienced it directly (Dell'Unto 2017), the really significant news in 3D GIS applications for archaeology is the ability to directly import, manage and analyse 3D models acquired on the field through range based (laser scanner) or image based (digital photogrammetry ) technologies. This new approach enables recording each stratigraphic unit during the excavations, and 
before their final removal. This is particularly useful when interpreting the data, since it enables researchers to (virtually) return to the excavations many times, and spatially place each layer in its original position, thus making it easier to read the relations across the various parts.

Even though the decision on how to acquire data on the field is often dictated by the specific requirements of the survey and by the characteristics of the site, the reduced processing times and the high precision that new software can currently achieve, often lead to the use of digital photogrammetry. The most popular software are presently the proprietary Photoscan software by Agisoft and Photomodeler, though open source solutions like Bundler and the free Micmac are also widely used.

The procedure entails transforming the acquired data into a Multipatch feature class, a particular type of geometric entity that enables visualizing the textured 3D model. Within a geodatabase, the Multipatch is created as any other point, line or polygon shapefile, and its attributes are like those of any other type of data.

The experiences mentioned above showed that a key advantage of the combined digital 3D and GIS models is given by the possibility of exploring (through visualization), investigating (through queries) and analysing (through the 3D Analyst), the complex reality of the artefacts through a heuristic approach, where the quantitative methods applied to detect the models, observe the relations, and identify the results of the queries, are highlighted directly by the surveyed objects (Landeschi 2016). In other words, the integration between the two technologies and the clear evolution in the way GIS platforms can manage 3D data, make it now possible to manage three-dimensional archaeological data for the interpretation of sites. The next step is likely to bring further improvement of three- dimensional data analyses, currently limited to data visualization, and the use of protocols that can turn these experimentations into a standard approach, with the use of work tools and technology that entail three dimensional workflows also part of the standard approach (Landeschi 2016).

\section{THE AMITERNUM BURIALS: EXCAVATION AND DOCUMENTATION}

Each archaeological site contains a lot of information, and issues like data management and scientific dissemination have always been confronting archaeologists. Appreciating the potential of IT applied to their subject, archaeologists keep finding ways to adapt modern technology to the objectives of their research (see above)

\subsection{Bio-archaeology and data management}

Archaeology often has to deal with excavating and researching funerary assemblages, that is contexts that host multiple burials, like medieval cemeteries, for example.

By the end of the 90s, bio-archaeology, a discipline blending archaeology, taphonomy and anthropology, was quite popular in Italy, as it stepped out of the shadows of archeothanatology in France in the 80s (Duday et al., 1990 and see Marinato, 2013 and bibliography for an overview of its evolution).

This discipline currently follows common protocols, which enable the recovery of great amounts of data, and when these are correctly put together and analysed, they provide a wealth of cultural and biological information on past populations: their relations with death, their lifestyle and health (Borgognini Tarli, Pacciani, 1993; Mallegni, Rubini, 1994; Canci, Minozzi, 2005; Mallegni, Lippi, 2009; Fornaciari, Giuffra, 2009).
Analysing funerary assemblages requires special attention because relatively limited contexts, such as tombs, contain a multitude of data resulting from several actions: the cut to dig the grave, the construction of the structure that hosts the dead, the laying of the body, its covering, the voluntary and involuntary post-laying actions.

On-field taphonomic analyses entail recording the position and movement of the skeletal districts, with a view to understanding the phenomena that interested the grave from the moment the individual was laid to the archaeological finding, including all phenomena related to decomposition.

After evaluating the integrity of the tomb, all characteristics of the grave need to be recorded (size, depth, walls and floor), the presence of structures (wall coverings, coffin, roofing, etc.), the layout inside the burial area, the orientation and relation with any other structure. Then the skeletal districts are analysed, and the characteristics that allow us to distinguish a primary burial (when decomposition took place in the site) from a secondary one (when the remains are not in the same place where they were originally buried). In the latter case, the factors that could have contributed to the phenomenon, for example a second funeral, reclaiming the cemetery land, recovering a family grave etc., need to be recorded.

In the event of primary burials, the anatomic connections are evaluated, distinguishing between labile and persistent joints, which helps understand the modes of decomposition: full, differed or empty space; these data enable us to assess the presence of funerary architectural elements made of perishable materials, such as wood caskets, covering boards, funerary pillows etc.

At this stage, it is important to also record the volumes of the thoracic cavity and the hips (in relation to the original anatomical volume) and the position of several districts, paying attention to the phenomenon defined as the 'wall effect' and the presence of compressions; these are features that help evaluate whether there were bandages or shrouds wrapping the body when it was laid.

It is also good to focus on the position of the body and the various skeletal districts, in order to evaluate, for example, any wish to turn the head or cross the arms of the dead, and the presence of grave goods, whether personal or ritual.

The ultimate objective is to understand which gestures where made around the dead at the time of their laying, also considering any diagenetic factor that may impact the burial, to avoid any interpretation errors.

This type of individual burial survey is important, but studying the entire funerary assemblage, that is crossing all data in order to reconstruct the organization of the burial grounds and their management over time, is essential for the definition of a possible burial rite (Duday, 2006). Clearly, in order to achieve detailed results, the data collected on the field need to be correlated with the results of the anthropological analyses carried out in the lab to determine the sex and the age of death, the family group, lifestyle and health.

Managing the (taphonomic and archaeological) data from individual burials and relating it with those obtained from the study of the entire funerary assemblage are not trivial tasks, and that is why archaeologists and anthropologists have perfected information systems that are based on GIS and records (Dadà, et al. 2007; Pisu, Naponiello, 2008; Minozzi, Zabotti, 2008; Coschino, et al. 2010; Amoretti, Nazionale, 2015; di Gennaro, et al. 2015). PYARCHINIT, a plug-in for QGis, is an interesting case of specific software developed by archaeologists with specifications for funerary archaeology and anthropology (Mandolesi, 2009; Mandolesi, Cocca, 2013).

These analyses are time consuming, since they depend on both the recovery of burials during the excavation phase (a 
university-led excavation may take several years) and the lab analyses, which are often carried out as $\mathrm{PhD}$ theses or undergraduate dissertations. If the study of the funerary assemblage is to be undertaken across several years, accurate recording of the field data and complete documentation are paramount.

\subsection{The burial grounds of Campo Santa Maria in Amiternum}

Around $10 \mathrm{~km}$ west of the city of L'Aquila, are the remains of the ancient Roman settlement of Amiternum (for an overview, see: Heinzelmann, 2012; Tuteri, 2014). A few yards from the amphitheatre, in the area of Campo Santa Maria, the on-going excavations directed by professor Fabio Redi of the University of L'Aquila, which started in 2012, brought to light the remains of the ancient cathedral and widened our knowledge of the Roman city, by surveying the stages of the early Christian years and its final abandonment (Figure 1). Related to the church structures, 65 primary and secondary burial sites from the 6th to the 13 th century were found, and also a 12th-13th century burial ground, which was set up but never used (Redi, et al. 2013; Id, 2014; Id, 2015; Id, 2016). Since 2012, the excavation stages have been documented with the standard archaeological tools, completed by taphonomic data sheets compiled with FileMaker Pro for the management of field data (Amoretti, Nazionale, 2015; Savini, 2015). The taphonomic data sheets were reviewed some time ago, following the templates proposed by other authors (Courtaud, 1996; Canci, Minozzi, 2005) and today they are old yet compliant with the ICCD standards proposed by the Ministry for anthropological findings (Mancinelli, 2016). The choice of programme was dictated by the characteristics of this database: non-rigid design operations also accessible to non-IT experts; compatibility with the use of iPads on the field, which is very common today (Fiorini, 2012; Fronza, 2012); relational databases that can communicate, ability to set up closed fields for data normalization and the elimination of subjective terms, reduced reviewing times.

The system also exports data in various different formats, thus facilitating communication with GIS systems, as already tested when exporting CVS tables linked with the vectorized and georeferenced skeletal data via shared SCH key, in order to study the entire funerary assemblage on the QGis platform (Savini, 2015).

\section{3D TAPHONOMIC ANALYSIS ON DIGITAL MODELS}

Given the importance of integrating the archaeological documentation with photogrammetry, the archaeology team at the University of L'Aquila widened its scope to include the integrating procedure on the field, and activated further collaborations, not just for the current excavation (Redi, Montagnetti, 2016).

Photogrammetry modelling for burials and funerary assemblages are unrivalled tools when it comes to objectively documenting data and carrying out $3 \mathrm{D}$ analysis, therefore, since 2016, the documentation of graves has included photo-realistic and adequately scaled digital models that can be viewed through Pdf3D.

Though we are aware that the presence of qualified professionals on the field cannot be substituted, we also believe that this kind of documentation may mitigate to some extent the issue that often characterizes archaeological sites, particularly those set up in emergency conditions, namely the absence of an anthropologist. While the photogrammetry model of the burial will inherit the subjectivity of its maker, since it is the result of choices made when bringing the burial to light (such as highlighting skeletal districts vs. leaving them covered, for reason of statics), we believe it may become a wonderful tool for comparisons with other experts' works.

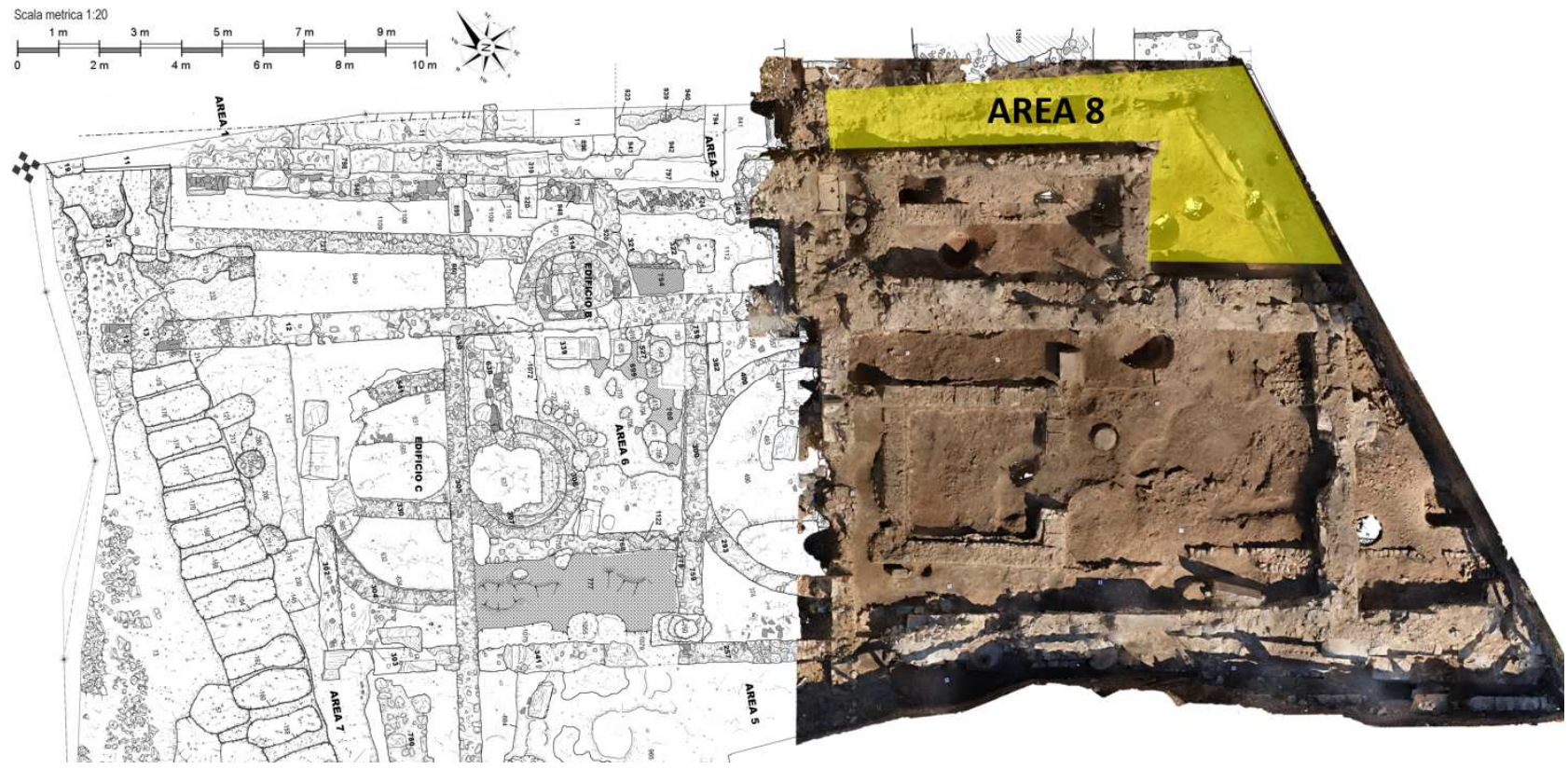

Figure 1. Planimetry of the excavation area with the overlapping of the orthophoto, exported by Photoscan, and the area 8 highlighted in yellow (Planimetry by A. Forgione). 

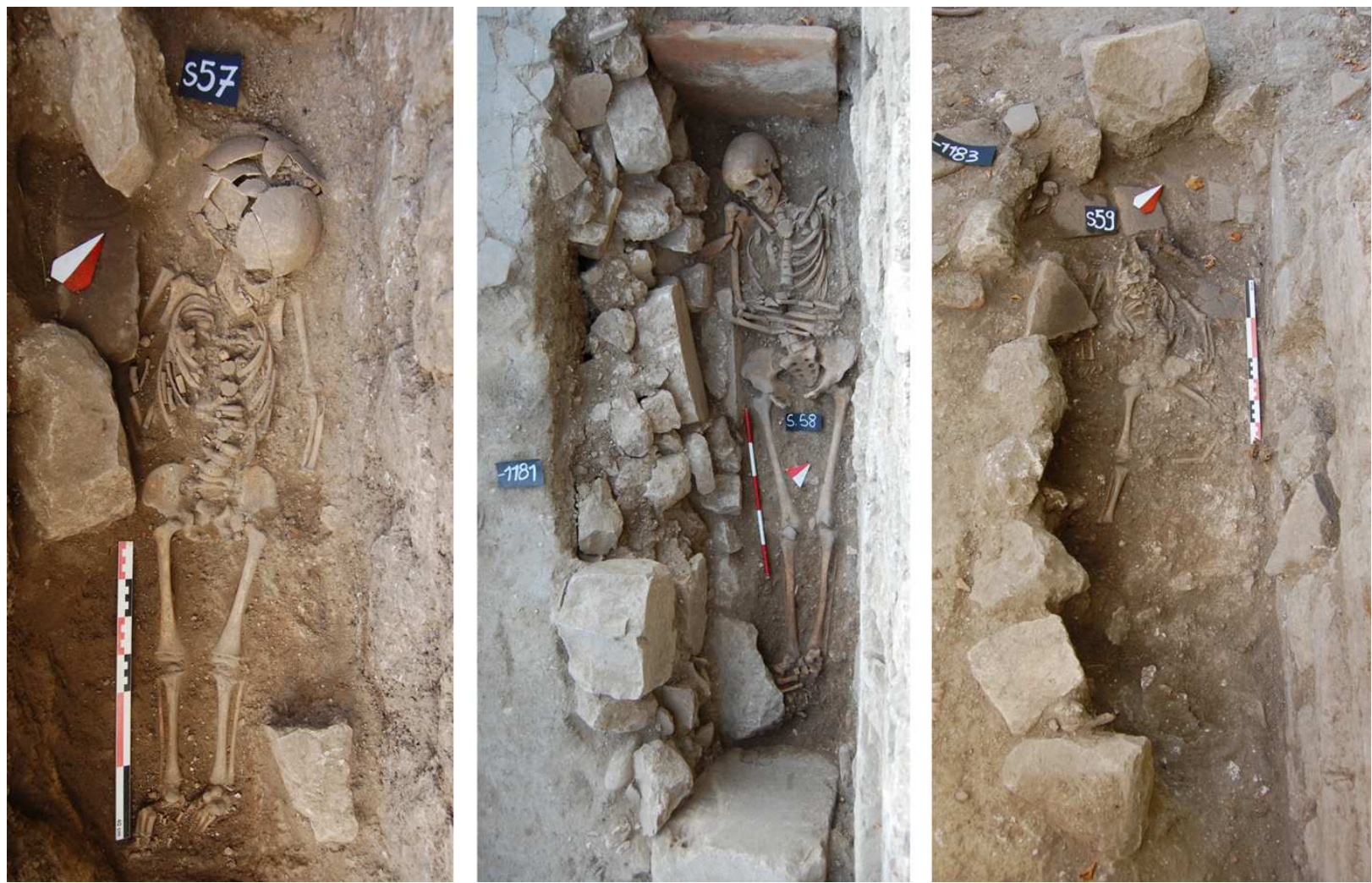

Figure 2. Photos of the burials subject of the experimentation.

For the anthropologists, the photogrammetry model is certainly useful, since the possibility of integrating the archaeoanthropological documentation within the model means that data can be reviewed even years later, which is a plus considering the timing of burial surveys.

During the 2017 excavations, a new experimentation was codeveloped with the Institute for Construction Technology of the L'Aquila CNR branch, entailing three-dimensional documentation with photogrammetry and taphonomic data managed within a 3D GIS environment, as detailed below.

We selected these two technologies, which are now quite popular in the field of archaeology (see above), because they make it possible to manage space, volume and alphanumeric information relating to different types of Stratigraphic Unit (empty grave, tomb structure, skeleton) in one environment, thus making it easier to analyse the data.

\subsection{Photography on the field}

The experimentation illustrated hereafter entailed the digital documentation of the burials discovered in Area 8, a little environment stretching between the excavation boundaries and the church walls; more specifically, tomb 36 (built for S.57 laid in grave SU-1179 and covered by SU+1180), tomb 37 (built for S.58 laid in grave SU-1181, lined with SU 1409 and covered by several tiles SU 1271 and SU 1182) and tomb 38 (built for S.59 laid in grave SU-1183 and covered by SU+1184) (Figure 2).

As mentioned earlier, the tomb is the result of several actions, hence, we adopted a procedure to survey all its characterizing SUs, beginning with the grave filler layers, then the covering (if there is one), the skeleton, the structure (if there is one) and the empty grave.

Picture taking on the field was thus dictated by the timing of the archaeology work, which is always longer for burials. After compiling the standard archaeology documentation, consisting of data sheets, photographs and graphs made with the help of the total station, we began photographing the SUs mentioned above.
As in any photo session prepared for photogrammetry modelling, we also faced the common problems linked to the presence of archaeologists on site and the exposure of the layers to sunlight (over exposure in the central hours and under exposure at dusk). To make it easier to process the photos, we set some markers that were directly extrapolated from the Photoscan software we used (see below), and geo-referenced with the total station.

\subsection{D taphonomic analysis and tomb reconstruction}

Taphonomic and anthropological data analysis carried out through GIS and digital modelling enabled us to assess the position of the bones linked by labile joints, such as the hand and foot phalanges, the position of the skull and the original volumes of the thorax and hips. This information helped us understand the mode of bodily decomposition and the original setting of the tomb.

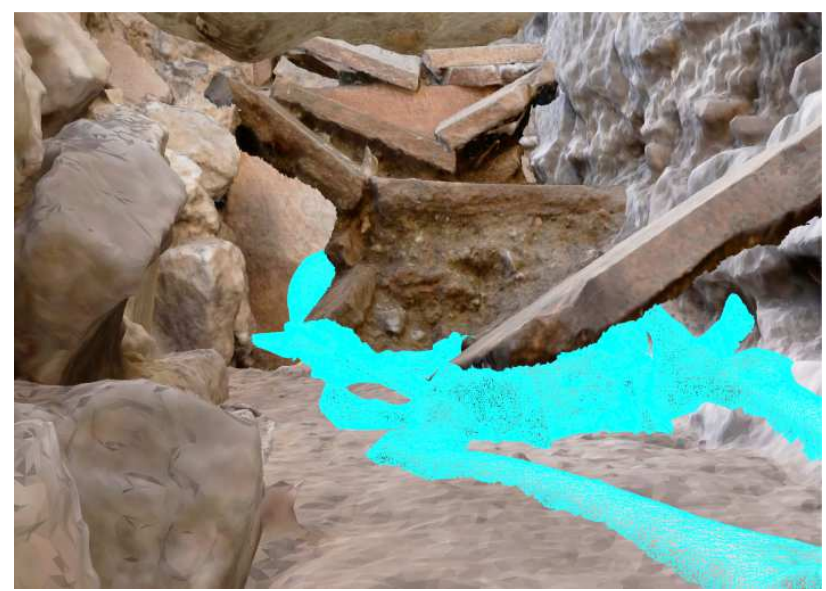

Figure 3. View of tomb 37 exported by Esri ArcScene: particular of the coverage collapsed on the skeleton. 

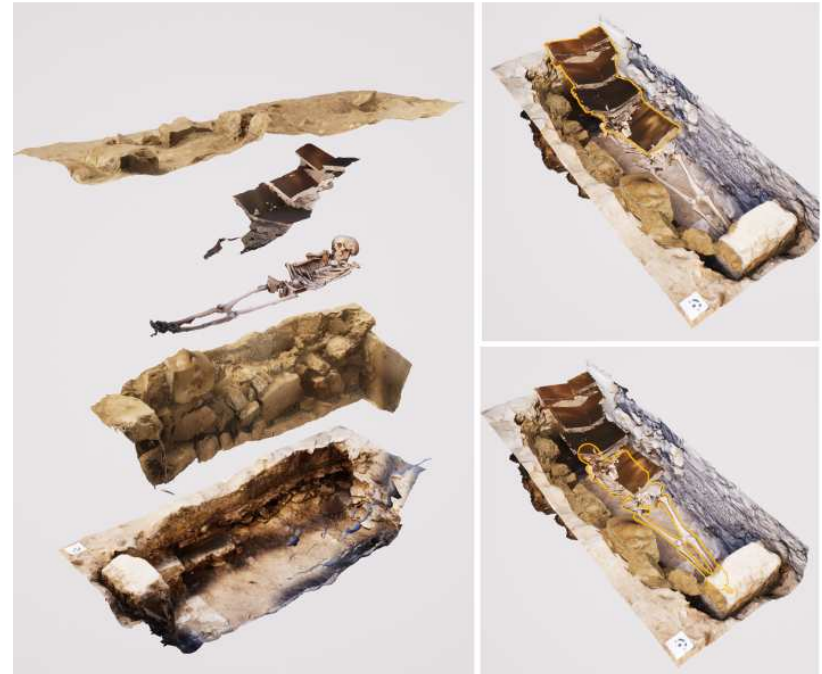

Figure 4. Digital model with the stratigraphic units that make up the tomb: figure exported to Abvent Twinmotion software.

On the skeletons, all in primary positioning, the anatomical connections were very loose or disconnected with the location of several districts; furthermore, there were clear signs of side rotations of the femurs, with the patellas also found in nonanatomical positions, loss of original thoracic volumes and the sliding of the sternum inside it. There were instances of 'wall effect', that is the alignment of several bones caused by the line border of the grave itself.

All these features point to a body that decomposed in an empty environment, with no sediment; this caused the movement of skeletal districts and the loss of the body's original volumes, as the soft tissue kept on decomposing.

These features also enable us to consider the possibility, for tombs 36 and 38 with no funerary structure, that a wood covering was rested directly over the stones located on the edge of the grave; a type of tomb that is often found in the L'Aquila region of Abruzzo (Redi, Savini, 2016).

This hypothesis is further enhanced by the presence of postmortem fractures on several skeletal districts, also confirmed by lab analysis. Their position was also assessed within the 3DGIS (see note infra) to better understand how the covering ceded following decomposition (Figure 3). In order to reconstruct the tomb's setting, we combined the photogrammetry model of the actual site with the modelling of the volumes and elements of funerary architecture that are no longer there.

The photogrammetry models of each unit were built with the Photoscan software, exported in the *dae format and then imported in SketchUp to model the volume of the filling and wood covering.

Within the Abvent Twinmotion software, each component was positioned in such a way that the tomb's stratigraphy was still visible. The model thus obtained not only validates the hypothesis generated by the taphonomic study, but also became a powerful means of communication to enhance the archaeological site of Campo Santa Maria in Amiternum (Figure 4).

\section{FROM PHOTOGRAMMETRY TO 3D GIS}

A recent study carried out in Sweden (Wilhelmson, Dell'Unto 2015) describes the procedure also adopted for the 3D GIS analysis of the burials discovered in Campo Santa Maria in Amiternum These two experimentations used similar methods (digital photogrammetry modelling combined with 3D GIS), and had several points of contact (visualizing and analysing human remains and their space relations within a virtually reconstructed archaeological context), but they also displayed significant differences: in Sweden, the procedure was used to obtain a virtual taphonomic analysis and the possibility of acquiring new data following specific queries; in Italy the 3D GIS stratigraphic analysis was mainly used to support site interpretations, formulating hypothesis on the original volumes of the burials and the wood covering.

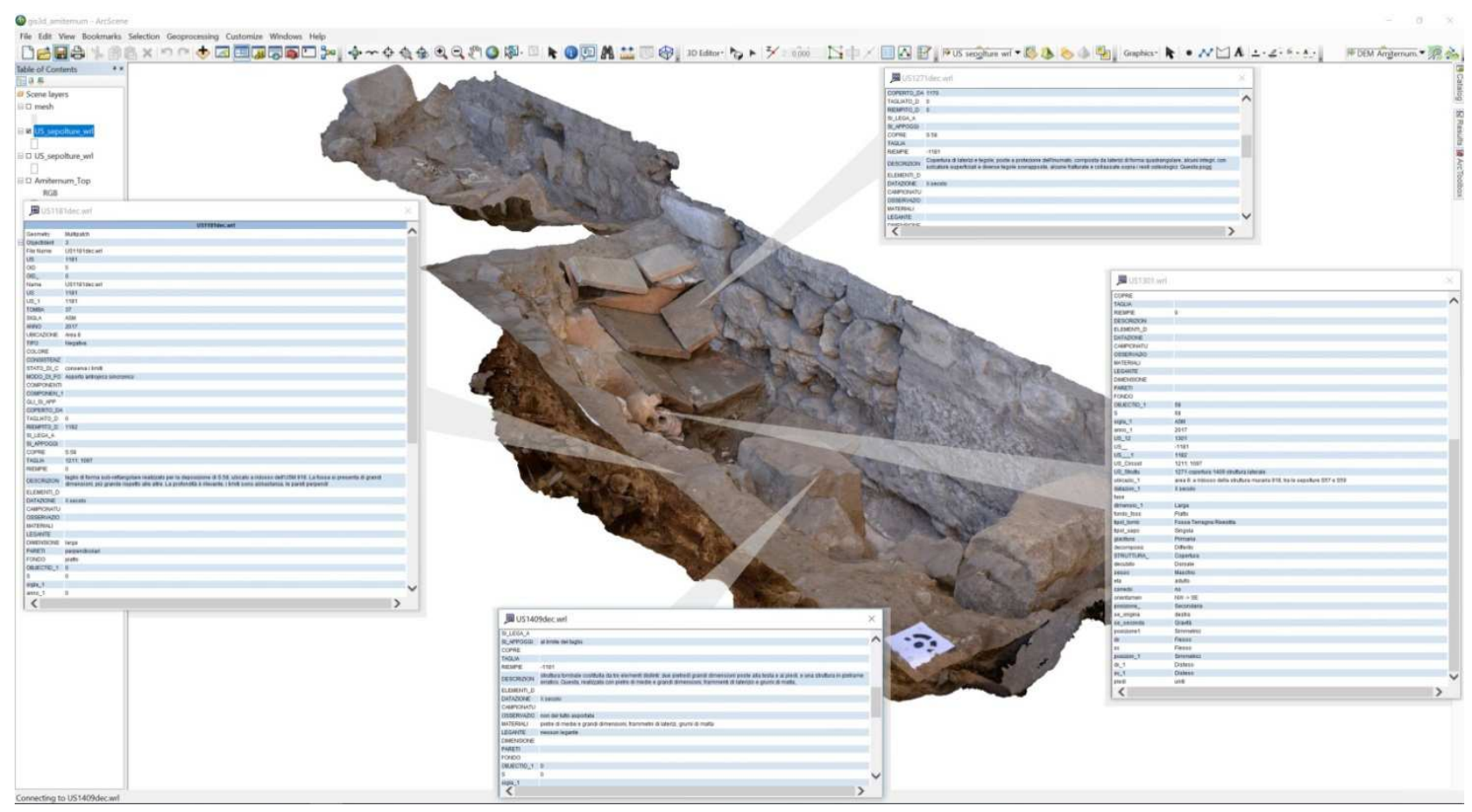

Figure 5. Screenshot from the Esri ArcScene software with highlighted, through the HTML Popup tool, informations related to the models of the stratigraphic units that make up the tomb.

This contribution has been peer-reviewed. 


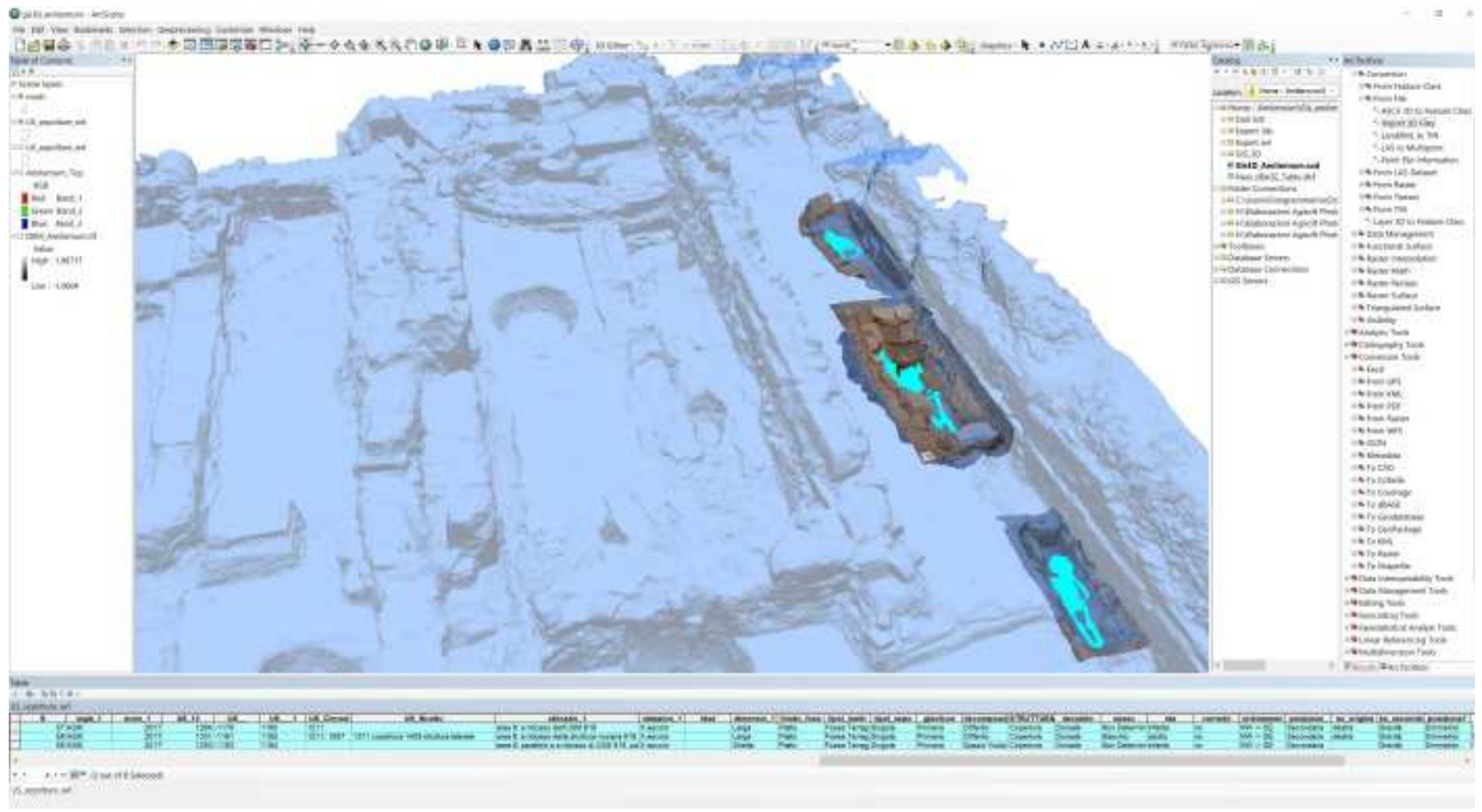

Figure 6. Screenshot from the Esri ArcScene software with highlighted skeletons and related informations.

In both instances, the same proprietary software was used (Agisoft Photoscan for the photogrammetry survey and the ArcScene module of ESRI's ArcGIS package for the 3D GIS).

\subsection{Integration methodology}

The images for the photogrammetry survey were acquired in several stages (see note supra) during the 2017 excavations, including the full excavation area and the three burials found inside Area 8. All photographs were taken with a Nikon D610 with GPS to enable geo-referencing the 3D model (WGS 84 (EPSG:4326); image processing was carried out with Agisoft Photoscan (release 1.2.6). The digital model of the entire excavation area required processing a set of 392 images with 165 markers, a total surveyed area of circa $280 \mathrm{~m}^{2}$, which made it possible to contextualize the surveyed burials and obtain a scale orthoimage of the entire excavation. The photogrammetry survey of the three burials required sets of 40 images (one for each SU), with the help of circa 20 markers per set. The digital modelling of tombs 36 and 38 only required processing three sets of images each, though tomb 38 required five sets of images. Using a procedure that the team had already tested (Trizio et alii, in review), the meshes obtained from each set, representing one SU each, were imported in the geo-database, after postprocessing in Photoscan (decimation, remeshing, closing the gaps). ArcScene, from Esri's ArcGIS 10.3.1 for Desktop package, was used to import data (using the *.3ds format), then convert it into a Multipatch feature class, a particular geometrical entity, via the Import 3D Files tool, found in the Conversion menu of the 3D Analyst Tools. Attributes that are topologically linked to the Multipatch features were highlighted through specific queries and directly queried through the Identify button, as any other attribute, on the 3D model mapped with high resolution texture (Figure 5 and 6).

\subsection{Geo-database architecture}

The 3D photogrammetry digital models of the SU were linked to the geo-database containing information on the burials, using the number of SUs as primary key. The structure of the GEO DBMS was organized in such a way that the taphonomic data (type, position, orientation, date, etc.) was linked with data from stratigraphic data sheets (state of conservation, stratigraphic relations, date, description, etc.). Furthermore, the data from the anthropological research were also connected, adding a link to visualize a 3D model of the pathological bones (Figure 7).

The database reported the dimensional data directly obtained from the model's analysis. The database has a flexible structure that can be easily used in novel implementations, depending on the needs that arise from the archaeology team or the laboratory analysis.

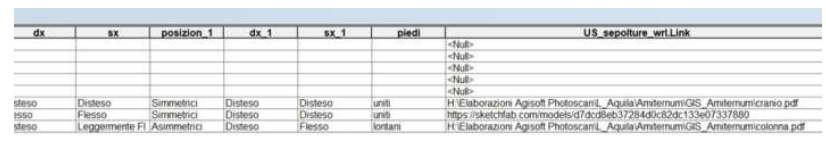

TOMBA 37 SCHELETRO 58

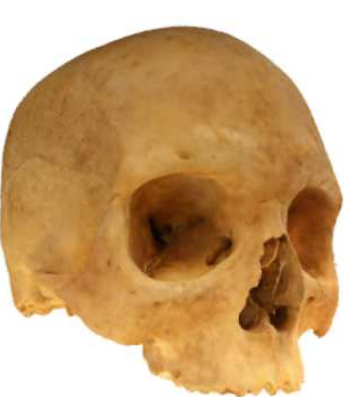

Stima dell'età alla morte

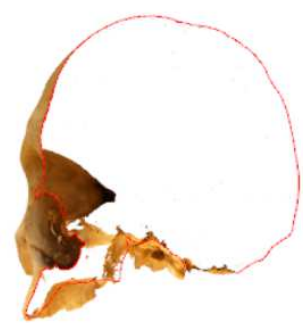

Caratteri metrici

Caratteri morfologici

Paleo-patologie

Figure 7. Database with the hyperlink and view of the pdf3D with 3D model of skull and its data. 


\section{CONCLUSIONS}

Although the potential of integrated photogrammetry models and 3D GIS for the interpretation of archaeological data is now established, our experimentation tested the effectiveness of these instruments for the analysis of funerary assemblages and individual burials. In addition to its standard ability to manage all heterogeneous data at the same time, 3D GIS enables us to assess the third dimension which is essential for taphonomic analyses and, especially, it enables us to document in 3D the space relation among stratigraphs that archaeologists remove during the excavations.

In the future, we hope that this tested procedure may be managed through web platforms, making the data available to researchers, and that three-dimensional GIS documentation may become the standard for the international scientific community.

\section{CREDITS}

Although this contribution was conceived as a single entity by all authors, Ilaria Trizio wrote paragraphs 1 and 4; Francesca Savini paragraphs 2 and 3; Alessandro Giannangeli was responsible for all stages of the 3D photogrammetry modelling of the case study (image acquisition, processing and postprocessing) and for creating the 3D GIS (MultiPatch creation, through to the relational database).

\section{ACKNOWLEDGEMENTS}

The authors would like to thank Prof. Fabio Redi and Dr. Alfonso Forgione for allowing our experimentation on the case study, data analysis and data management regarding the burials unearthed during the 2017 excavations.

\section{REFERENCES}

Amoretti, V., Nazionale, V., 2015. Evolution of techniques in osteoarchaeology: a proposal for a new on field schedule for preliminary study of ancient population. In Gambardella C. (eds), Heritage and technology. Mind Knowledge Experience, pp. 1836-1847.

Baldassarri, M., Naponiello, G., Pagni, G., 2007. L'Open Source in archeologia. Elaborazione di un sistema di schedatura e sviluppo di un web GIS per la consultazione dei dati archeologici: il caso di Montescudaio in Val di Cecina (PI). In Costa S., Pesce G-L. (eds), Atti del II workshop Open Source, Free Software e Open Format nei processi di ricerca archeologica, (Genova, 11 maggio 2007), pp. 51- 74.

Borgognini Tarli, S., Pacciani, E., 1993. I resti umani nello scavo archeologico. Metodiche di recupero e studio. Bulzoni editore, Roma.

Canci, A., Minozzi, S., 2005. Archeologia dei resti umani. Dallo scavo al laboratorio. Carocci editore, Roma.

Continenza, R., Trizio, I., 2015. The SIArch-Univaq, an Architectural Information System for Cultural Heritage, in Brusaporci, S. (ed.), Handbook of Research on Emerging Digital Tools for Architectural Surveying, Modeling, and Representation, vol. I, IGI Global, Hershey, pp. 318-343.

Coschino, F., Fornaciari, A., Minozzi, S., 2010. Computer models and applications for the management of anthropological data. Journal of Anthropological Sciences, 89, pp. 195-199.
Courtaud, P., 1996. «Anthropologie de sauvetage»: vers une optimisation des méthodes d'enregistrement. Présentation d'une fiche anthropologique. Bulletins et Mémoires de la Société d'anthropologie de Paris, 8, fascicule 3-4, pp. 157-167.

Dadà, M., Naponiello, G., Paribeni, E., 2007. Fivizzano (MS). Monte dei Bianchi: monastero medievale di San Michele Arcangelo, prima campagna di scavi (agosto 2007). Notiziario della Soprintendenza per i Beni Archeologici della Toscana, 3, pp. 22-30.

Dell'Unto, N., 2017. Using 3D GIS Platforms to Analyse and Interpret the Past. In Forte, M., Campana, S. (eds.), Digital Methods and Remote Sensing in Archaeology. Archaeology in the Age of Sensing. Springer International Publishing, Cham, pp. 305-322.

Dell'Unto, N., Landeschi, G., Leander Touati, A. M., Delle Piane, M., Callieri, M., Ferdani, D., 2016. Experiencing Ancient Buildings from a 3D GIS Perspective: a Case Drawn from the Swedish Pompeii Project. Journal of Archaeological Method and Theory, 23, Issue 1, pp. 73-94.

di Gennaro, F., Filippini, P., Malizia, A., Ceccarelli, A., Cecchetti, A., Attema, P., Seubers, J., 2015. La sistematizzazione dei dati del III (già IV) municipio: Prospettive di ricerca e sviluppo. Archeologia e Calcolatori, suppl. 7, pp. 297-309.

Duday, H, Courtaud, P, Crubezy, E, Sellier, P, Tillier, AM. 1990. L'anthropologie «de terrain»: reconnaissance et interpretation des gestes funeraires. Bulletins et Mémoires de la Société d'anthropologie de Paris, 2, pp. 29-49.

Duday, H., 2006. Lezioni di archeotanatologia. Archeologia funeraria e antropologia sul campo. Istituto Arti Grafiche Mengarelli, Roma.

Fiorini, A. 2012. Tablet PC, fotogrammetria e PDF 3D: strumenti per documentare l'archeologia. Archeologia $e$ Calcolatori, 23, pp. 213-227.

Fornaciari, G., Giuffra, V., 2009. Lezioni di paleopatologia. ECIG, Genova.

Forte, M., (ed) 1997. Virtual Archaeology. Re-creating Ancient Worlds. Thames and Hudson, London.

Forte, M., 2002. I Sistemi Informativi Geografici in Archeologia. Mondo Gis, Roma.

Forte, M., 2017. Cyber Archaeology: 3D Sensing and Digital Embodiment. In Forte M., Campana S. (eds.), Digital Methods and Remote Sensing in Archaeology. Archaeology in the Age of Sensing. Springer International Publishing, Cham, pp. 271-289.

Forte, M., Campana, S. (eds.), 2017. Digital Methods and Remote Sensing in Archaeology. Archaeology in the Age of Sensing. Springer International Publishing, Cham.

Forte, M., Dell'Unto, N., Jonsson, K., Lercari, N., 2015. Interpretation process at Çatalhöyük using 3D. In Hodder, I., Marciniak, A. (eds.), Assembling Çatalhöyük, vol. 1 Themes in Contemporary Archaeology, vol. 1, Maney, Leed. 
Fronza, V., 2012. Lo scavo 2.0: "tablet" e gestione "live" dei dati. In Redi, F., Forgione, A. (eds), Atti del VI Congresso Nazionale di Archeologia Medievale (L'Aquila 12-15 settembre 2012), pp. 59-64.

Heinzelmann, M., 2012. Amiternum (San Vittorino AQ). Prospezioni e scavi 2010. Quaderni di Archeologia d'Abruzzo, 2/2010, pp. 484-487.

Landeschi, G., 2016. Assessing the damage of an archaeological site: New contributions from the combination of image-based 3D modelling techniques and GIS. Journal of Archaeological Science: Reports, 10, pp. 431-440.

Landeschi, G., Dell'Unto, N., Lundqvist, K., Ferdani, D., Campanaro, D. M., Leander Touati, A. M., 2016. 3D-GIS as a platform for visual analysis: Investigating a Pompeian house. Journal of Archaeological Science, 65, pp. 103-113.

Leander Touati, A.M., Campanaro, D.M., Landeschi, G., Dell'Unto, N., 2016. 3D GIS for cultural heritage restoration: A 'white box' workflow. Journal of Cultural Heritage, 18, pp. 321-332.

Mallegni, F., Lippi, B., (eds) 2009. Non Omnis Moriar. CISU, Roma.

Mallegni, F., Rubini, M. (eds), 1994. Recupero dei materiali scheletrici umani in archeologia. CISU, Roma.

Mancinelli, M. L., 2016. Beni archeologici mobili: indicazioni applicative. Mibact-ICCD, [ultima consultazione 21-03-2018] file://C:/Users/Utente/Downloads/Beni\%20archeologici\%20mo bili_indicazioni\%20applicative_mag2016.pdf

Mandolesi, L., 2009. PYARCHINIT - PYTHON, QGIS e POSTGRESQL per la gestione dei dati di scavo. Archeologia e Calcolatori, suppl. 2, pp. 209-222.

Mandolesi, L., Cocca, E., 2013. PYARCHINIT: gli sviluppi dopo ARCHEOFOSS 2009. Archeologia e Calcolatori, suppl. 4, pp. 128-138.

Marinato, M., 2013. Gli studi di bioarcheologia dei cimiteri medievali in Italia. European Journal of Post-Classical Archaeologies, 3, pp. 113-130.

Minozzi, S., Zabotti, F. 2008. Elaborazione di metodiche comuni: una banca dati archeologica ed antropologica per la gestione dei dati di scavo. In Scheid J. (eds), Pour une archéologie du rite. Nuvelle perspectives de l'archéologie funéraire, pp. 337-349.

Nucciotti, M., Drap, P., Papini, O., Pruno, E., Vannini, G., 2017. Ontology-based photogrammetry survey for medieval archaeology: Toward a 3D geographic information system (GIS). Geosciences, 7, pp. 0-32.

Pisu, N., Naponiello, G., 2008. Libera circolazione di dati archeologici: il caso dello scavo di S. Vigilio di Ossana (TN). In Bezzi L., Francisci D., Grossi P., Lotto D. (eds), Open Source, Free Software e Open Format nei processi di ricerca archeologica, Atti del III Workshop (Padova, 8-9 maggio 2008), pp. 69-84.
Redi, F., Forgione, A., Savini, F., Russi, A., Siena, E., De Iure, A., 2014. Amiternum (AQ). Scavo archeologico in località "Campo S. Maria". Relazione preliminare, scavo 2013. Archeologia Medievale, XLI, pp. 171-194.

Redi, F., Forgione, A., Savini, F., Siena, E., De Iure, A., Ciammetti, E., 2013. Amiternum (AQ), "Campo Santa Maria", rapporto preliminare 2012. Archeologia Medievale, XL, pp. 267-285.

Redi, F., Forgione, A., Siena, E., Ferretti, L., Calabrese, L., 2016. Amiternum (AQ). "Campo S. Maria", campagna di scavo 2015. Archeologia Medievale, XLII, pp. 141-164.

Redi, F., Forgione, A., Siena, E., Savini, F., Ciammetti, E, 2015. Il sito di "Campo Santa Maria" dall'età tardoantica al cimitero del XIII-XIV secolo. Primi risultati nelle ricerche della cattedrale di Amiternum (AQ). In Arthur, P., Imperiale M. L. (eds), Atti del VII Congresso Nazionale di Archeologia Medievale (Lecce, 9-12 settembre 2015), Volume 2, pp. 176181.

Redi, F., Montagnetti, R., 2016. "Motte" normanne nel territorio del Parco Regionale "Sirente-Velino" (AQ) definite tramite l'uso delle nuove tecnologie nel survey archeologico. Archeologia Medievale, XLIII, pp. 165-183.

Redi, F., Savini, F.,2016. Luoghi di culto e cimiteri fra tarda antichità e medioevo nell'alta valle dell'Aterno (AQ). Un aggiornamento delle ricerche. In Ebanista, C., Rotili, M. (eds), Territorio, Insediamenti e Necropoli fra Tarda Antichità e Alto Medioevo, Atti del convegno internazionale di studi Cimitile Santa Maria Capua Vetere (19-20 giugno 2014), pp.447-468.

Savini, F., 2015. L'analisi dei cimiteri dell'Abruzzo aquilano dall'XI al XVI secolo. Tesi di dottorato in Archeologia Medievale, Università degli Studi dell'Aquila, tutor: Fabio Redi.

Trizio, I., Savini, F., Marchetti, A., Redi, F., Continenza, R., Giannangeli, A., (in review). Photogrammetric survey and 3D GIS managemetn of mesh in the integrated investigation of complex sites. The case study of the archaeological complex of the Terme di Vespasiano at Cittaducale (RI), Italy. In Inglese C., Ippolito A., (eds.), Analysis, Conservation, and Restoration of Tangible and Intangible Cultural Heritage, IGI Global.

Tuteri, R., 2014. Il territorio amiternino nella tarda romanità. Appunti. In Redi, F., Forgione, A. (eds), La chiesa di S. Paolo di Barete (AQ). Dallo scavo al restauro. Venti secoli di storia riscoperti, All’insegna del giglio, Firenze, pp. 13-34.

Wilhelmson, H., Dell'Unto, N., 2015. Virtual Taphonomy: A New Method Integrating Excavation and Postprocessing in an Archaeological Context. American Journal of Physical Anthropology, 157, pp. 305-321. 